MERCATORIA

Available online http://ojs.uma.ac.id/index.php/mercatoria

\title{
Pelaksanaan Pasal 1131 KUHPerdata atas Jaminan Benda Milik Debitur
}

\author{
Jamillah* \\ Universitas Medan Area \\ *Corresponding author: E-mail: jamilah@uma.ac.id
}

\begin{abstract}
Abstrak
Kreditur memberikan dana kepada debitur tanpa adanya jaminan atas pembayaran kembali utang. Suatu utang disebut tanpa jaminan apabila transaksi itu tidak dijamin dengan benda atau barang tertentu yang sengaja diberikan debitur untuk menjamin pemenuhan kembali pembayaran utang. Dalam pemenuhan kembali pembayaran utang oleh debitur kepada kreditur adakalanya lancar dan juga tidak lancar. Penyelesaian utang debitur yang tidak lancar inilah pada akhirnya akan menyita harta benda atau kekayaan debitur yang menjadi jaminan utangnya. Cara yang dapat ditempuh kreditur apabila debitur wanprestasi melalui gugatan ke Pengadilan Negeri dan kreditur meminta Pengadilan Negeri terhadap harta kekayaan debitur diletakkan sita jaminan. Apabila debitur tidak melaksanakan isi putusan secara sukarela, maka Ketua Pengadilan Negeri harus menegur debitur supaya menjalankan putusan. Jika teguran tidak ditanggapi debitur, maka harta kekayaan yang telah diletakkan sita jaminan barang tidak bergerak merupakan milik kreditur.
\end{abstract}

Kata kunci : Pasal 1131 KUHPerdata, Jaminan benda milik debitur

\begin{abstract}
The creditor provides funds to the debtor without any guarantee of debt repayment. A debt is called unsecured if the transaction is not secured by certain objects or goods that the debtor deliberately grants to guarantee the fulfillment of debt repayment. In the repayment of debt payments by the debtor to the creditor is sometimes smooth and also not smooth. Debt debt settlement that is not smoothly this will eventually seize property or wealth of the debtor who becomes the guarantee of its debt. The way that the creditor can be taken if the debtor wanprestasi through a lawsuit to the District Court and the creditor to ask the District Court against the debtor's property placed seizure of collateral. If the debtor does not implement the decision voluntarily, then the President of the District Court must reprimand the debtor in order to execute the verdict. If the reprimand is not responded by the debtor, then the property which has been placed confiscation of immovable goods belongs to the creditor.
\end{abstract}

Keyword: Articel 1131 Civil Code, Debtor Guarantee

How to Cite: Jamillah., (2017), Pelaksanaan Pasal 1131 KUHPerdata atas Jaminan Benda Milik Debitur, Mercatoria, 10 (2): 137-159. 
Jamillah, Pelaksanaan Pasal 1131 KUHPerdata atas Jaminan Benda Milik Debitur

\section{PENDAHULUAN}

Pembangunan

ekonomi yang

dilaksanakan pada masa sekarang diarahkan untuk meningkatkan

pendapatan masyarakat dan mengatasi ketimpangan ekonomi guna mencapai kesejahteraan manusia secara berkesinambungan. Perkembangan ekonomi akan diikuti oleh kebutuhan akan kredit dan pemberian kredit tersebut dengan adanya jaminan dalam pemberian kredit merupakan keharusan yang tidak dapat dihindari. Bagi kaum pengusaha, mengambil utang (kredit atau pinjaman) sudah merupakan faktor yang tidak dapat dipisahkan dari kehidupan bisnis. ${ }^{1}$ Dengan demikian berkembangnya kegiatan ekonomi maka akan semakin perlunya sumber-sumber dana untuk membiayai suatu kegiatan usaha.

Dalam Pasal 1 butir 11 UU Nomor 10 Tahun 1998 dirumuskan bahwa kredit adalah penyediaan uang dan tagihan yang dapat dipersamakan dengan itu, berdasarkan persetujuan atau kesepakatan pinjam meminjam antara bank dengan pihak lain yang mewajibkan pihak peminjam untuk melunasi utangnya setelah jangka waktu tertentu dengan pemberian bunga. ${ }^{2}$

\section{Dalam}

mengembangkan pelaksanaan kegiatan Pembangunan dengan berdasarkan prinsip ekonomi yaitu dengan pengorbanan sekecilkecilnya dapat diperoleh keuntungan yang sebesar-besarnya, maka pada umumnya tujuan kredit secara ekonomis adalah

1 Tan Kamelo, Jaminan Fidusia Suatu Kebutuhan yang Didambakan, Penerbit Alumni, Bandung, 2004, hal. 2

2 Hermansyah, Hukum Perbankan Nasional Indonesia, Prenada Media, Jakarta, 2005, hal. 55 untuk mendapatkan keuntungan. ${ }^{3}$

Didalam pemberian kredit, bank harus memperhatikan asas-asas perkreditan yang sehat termasuk resiko yang harus dihadapi atas pengembalian kredit. Untuk memperoleh keyakinan sebelum memberikan kredit, bank harus melakukan penilaian yang seksama terhadap watak, kemampuan, modal, agunan dan prospek usaha debitur. Agunan merupakan salah satu unsur jaminan kredit agar bank dapat memperoleh tambahan keyakinan atas kemampuan debitur untuk mengembalikan utangnya.

Pada dasarnya pemberian kredit dapat diberikan oleh siapa saja yang memiliki kemampuan, untuk itu melalui perjanjian utang piutang antara Pemberi utang (kreditur) di satu pihak dan Penerima utang (debitur) di lain pihak. Setelah perjanjian tersebut disepakati, maka lahirlah kewajiban pada diri kreditur, yaitu untuk menyerahkan uang yang diperjanjikan kepada debitur, dengan hak untuk menerima kembali uang itu dari debitur pada waktunya, disertai dengan bunga yang disepakati oleh para pihak pada saat perjanjian pemberian kredit tersebut disetujui oleh para pihak. Hak dan kewajiban debitur adalah bertimbal balik dengan hak dan kewajiban kreditur. Selama proses ini tidak menghadapi masalah dalam arti kedua pihak melaksanakan hak dan kewajibannya sesuai dengan yang diperjanjikan, maka persoalan tidak akan muncul. Biasanya persoalan baru muncul jika debitur lalai mengembalikan uang pinjaman pada saat

3 Thomas Suyatno, dkk., Dasar-dasar Perkreditan, Penerbit PT. Gramedia, 1990, hal. 13 
yang telah diperjanjikan. ${ }^{4}$

Jika terjadi demikian, Pasal 1131

Kitab Undang-undang Hukum Perdata (KUHPerdata) menentukan sebagai berikut "Segala kebendaan si berutang baik yang bergerak maupun yang tak bergerak, baik yang sudah ada maupun yang baru akan ada di kemudian hari, menjadi tanggungan untuk segala perikatannya perseorangan".

Walau ditegaskan secara demikian, pada prakteknya seorang debitur tidak hanya terikat pada hanya satu macam kewajiban saja. Kondisi yang demikian menyebabkan kreditur merasa tidak aman dan untuk memastikan pengembalian uangnya, maka kreditur tentunya akan meminta kepada debitur untuk mengadakan perjanjian tambahan guna menjamin dilunasinya kewajiban debitur pada waktu yang telah disepakati sebelumnya diantara kreditur dan debitur.

Untuk menjamin pelunasan utang dari pihak debitur pada waktunya, seringkali kreditur tidak akan memberi kredit jika tidak ada jaminan, dan perjanjian pemberian jaminan itu sendiri tidak mungkin lahir selain harus didahului dengan adanya suatu perjanjian pokok yang mendasari lahirnya utang piutang atau kewajiban dari pihak debitur kepada kreditur.

Sebelum melakukan perjanjian kredit, terlebih dahulu dilakukan perjanjian, dimana perjanjian merupakan persetujuan yang mengikat kedua belah pihak atau menurut undang-undang yang berlaku, disebut juga hukum perikatan,

4 Gunawan Widjaya dan Ahmad Yani, Jaminan Fidusia, Jakarta, PT. Raja Grafindo Persada, 2011, hal. 3 yang di dalamnya harus dijalankan atau dipenuhi prestasi oleh pihak yang berutang. 5

Perjanjian merupakan sumber terpenting yang melahirkan perikatan. ${ }^{6}$ Selain perikatan diterbitkan oleh suatu perjanjian, ada juga perikatan yang lahir dari undang-undang. Perikatan yang lahir dari perjanjian yaitu kesepakatan yang dikehendaki oleh dua orang atau lebih dalam membuat suatu perjanjian, di luar kemauan para pihak yang bersangkutan.

Menurut Pasal 1320 KUH Perdata bahwa syarat-syarat perjanjian adalah :

1. Sepakat mereka yang mengikatkan dirinya

2. Cakap untuk membuat suatu perikatan

3. Suatu hal tertentu

4. Suatu hal yang halal. ${ }^{7}$ Dalam perkembangan pembangunan ekonomi pada saat ini banyak kita temui kreditur meminjamkan uangnya atau hartanya pada nasabah, dalam hal ini debitur meminjam uang kepada bank yang mana debitur harus membayar kreditnya, tetapi debitur tidak sanggup untuk melunasi Utangnya, apabila debitur cidera janji atau wanprestasi sedangkan transaksi kredit tidak diikat secara asesor dengan perjanjian jaminan barang tertentu yang telah diketahui dengan pasti barang tersebut milik debitur, maka disarankan akan kreditur di dalam mengajukan gugatan perdata ke

5 R. Subekti, Hukum Perjanjian, Penerbit Intermasa, Jakarta, 1985, hal. 1

${ }^{6}$ J. Satrio, Hukum Perikatan, Perikatan yang Lahir dari Perjanjian, Buku I, PT. Citra Aditya Bakti, Bandung, 2001, hal. 17

${ }^{7}$ Mariam Darus Badrulzaman, dkk, Kompilasi Hukum Perikatan, PT. Citra Aditya Bakti, Bandung, 2001, hal. 73 
Pengadilan Negeri langsung meminta sita jaminan atas harta kekayaan debitur yang tidak diperjanjikan tersebut.

Dalam menganalisis jaminan yang tidak diperjanjian baik yang terdapat dalam putusan-putusan pengadilan maupun perjanjian utang yang tidak diperjanjikan yang terjadi dan peraturan perundang-undangan yang mengatur jaminan yang tidak diperjanjian, diperlukan pendekatan sistem (approach system).

Apabila debitur wanprestasi sedangkan transaksi kredit tidak diikat secara asesor dengan perjanjian jaminan barang tertentu, sehingga jaminan pemulihannya tunduk kepada ketentuan Pasal 1131. Maka disini timbul permasalahan yang dihadapi oleh kreditur dimana kreditur tidak melakukan jaminan utang apabila debitur wanprestasi sehingga kreditur sulit untuk mengambil jaminan utang debitur karena dalam melakukan kredit tidak ada jaminan diberikan oleh debitur.

\section{METODE PENELITIAN}

Penelitian ini bersifat deskriptif analitis. Penelitian ini merupakan Penelitian kepustakaan (library research) yaitu dengan melakukan penelitian terhadap berbagai sumber bacaan yaitu buku-buku, majalah hukum, pendapat para sarjana dan juga bahan-bahan pendukung lainnya.

\section{HASIL DAN PEMBAHASAN}

Pasal 1238 KUH Perdata menetapkan bahwa seorang berutang dinyatakan telah lalai memenuhi prestasinya bila berdasarkan suatu surat perintah atau akta sejenisnya dinyatakan demikian, kecuali jika perikatannya sendiri telah menetapkan bahwa si berutang harus dianggap lalai dengan lewatnya waktu yang ditentukan. Surat perintah adalah pernyataan resmi dari juru sita pengadilan, sedangkan akta sejenis adalah peringatan tertulis. ${ }^{8}$ Debitor yang sudah diperingatkan dan secara tegas ditagih janjinya, tetapi tetap tidak melaksanakan prestasinya maka salah satu upaya hukum yang dapat ditempuh oleh kreditor untuk mendapatkan pembayaran adalah mengajukan gugatan perdata melalui pengadilan.

Untuk mendapatkan kepastian bahwa debitor akan memenuhi kewajibannya sebagaimana yang ditetapkan, penggugat (pihak kreditor) dalam gugatannya harus meminta putusan provisional, yaitu meminta diletakkan sita jaminan (conservator beslag) terhadap harta kekayaan tertentu debitor. Dengan demikian, apabila dikemudian hari debitor dikalahkan akan tetapi tidak mau melaksanakan putusan secara sukarela, maka kreditor dapat meminta bantuan Ketua Pengadilan Negeri untuk melaksanakan putusan itu secara paksa berdasarkan Pasal 207 RBg. Pelaksanaan putusan pengadilan menurut RBg dengan melalui peringatan (aanmaning). Pelaksanaan putusan secara paksa ini disebut eksekusi. Jika sudah lewat jangka waktu yang ditetapkan pengadilan pihak yang dikalahkan tidak memenuhi putusan atau tidak datang menghadap, sesuai dengan ketentuan Pasal 208 RBg harta benda debitor sampai jumlah yang dianggap cukup disita oleh pengadilan, dan dijual melalui KPKNL.

Dalam transaksi perkreditan atau

\footnotetext{
${ }^{8}$ R. Subekti, Op. Cit., hal. 44
} 
peminjaman uang, terdapat dua jenis perikatan ditinjau dari segi pemenuhan pembayaran kembali uang yang dipinjam. Pertama, transaksi kredit "tanpa jaminan" atau unsecured transaction:

1. Tidak ada jaminan (not guaranteed) atau tidak ada perlindungan (not protected) atas pemenuhan pembayaran kembali utang;

2. Dalam hal ini, pelunasan pembayaran kembali utang, tidak dijamin dengan suatu barang yang mempunyai nilai atau harga yang sama atau melebihi jumlah pinjaman;

3. Itu sebabnya, ditinjau dari berbagai aspek, transaksi tersebut dapat dikategori:

a. dari aspek bisnis, transaksi seperti ini disebut utang tanpa jaminan (unsecured debt);

b. dari aspek yuridis, dikategori tuntutan tanpa jaminan (unsecured claim), dan kreditornya dikategori kreditor tanpa jaminan (unsecured creditor).

Kedua, transaksi kredit yang "dilindungi jaminan" atau secured transaction:

1. Terhadap utang atau pinjaman, debitur memberi barang jaminan sebagai perlindungan pemenuhan pembayaran kepada kreditor;

2. Apabila debitur ingkar atau lalai memenuhi pembayaran utang sebagaimana mestinya sesuai dengan perjanjian, pemenuhan dapat dipaksa (imposed) dengan jalan eksekusi barang jaminan melalui "penjualan lelang" oleh kreditor atau melalui pengadilan:

a. Dari segi bisnis; dikategori transaksi utang dilindungi jaminan (secured debt), dan kreditor berada dalam posisi terjamin (secured creditor);

b. dari segi hukum; tuntutan pemenuhan pembayaran utang dilindungi barang jaminan, sehingga dikategori secured claim dengan jalan menjual atau mengeksekusi barang jaminan melalui pengadilan.

Bertitik tolak dari ketentuan perundang-undangan yang berlaku, pada saat sekarang, terdapat beberapa bentuk perjanjian kredit yang dilindungi dengan jaminan yang memiliki "hak prefensi" dan "separatis", yaitu:

1) Hak Tanggungan (HT) berdasarkan ULJ No. 4 Tahun 1996;

2) Jaminan Fidusia $(\mathrm{H})$ berdasarkan UU No. 42 Tahun 1999;

3) Hak Gadai (Pandrecht) berdasarkan Pasal 1150-1161 KUH Perdata

4) Hipotek Kapal berdasarkan Pasal 314 KUHD jo. Pasal 1162-1232 KUH Perdata;

5) Hipotek Pesawat Terbang berdasarkan Pasal 12 ayat (1) UU No. 1, Tahun 1992 jo. Pasal 1162-1232 KUH Perdata.

Suatu utang disebut tanpa jaminan, apabila transaksi itu:

a. "tidak dijamin" dengan benda atau barang tertentu yang sengaja diberikan debitur untuk menjamin pemenuhan kembali pembayaran utang;

b. dengan demikian, utang atau pinjaman "tidak dilindungi" barang agunan yang bersifat spesialis dengan hak separatis dan preferen, sehingga kredit (tidak memiliki hak utama atas pemenuhan pembayaran utang (preferen vordering, preferential debt) dari kreditor lain;

c. kedudukan kreditor terhadap harta 
Jamillah, Pelaksanaan Pasal 1131 KUHPerdata atas Jaminan Benda Milik Debitur

kekayaan debitur dalam rangka pemenuhan kembali pembayaran utang, bersifat konkuren (concurrent atau bersaing dengan kreditor yang lain.

Pada prinsipnya, tidak ada utang debitur yang tidak dijamin. Pasal 1131 KUH Perdata telah menegaskan hal berikut:

a. Harta Benda atau Kekayaan Debitur Menjadi Jaminan Utang

Segala harta benda atau kekayaan debitur:

1) baik yang bergerak (movable goods) dan tidak bergerak (unmovable goods);

2) baik yang ada sekarang maupun yang ada di kemudian hari, menjadi tanggungan atau jaminan (zekerheid, haftung) untuk segala perikatan perorangan yang dibuatnya;

a) akan tetapi, berdasarkan Pasal 1131 KUH Perdata, harta kekayaan atau kebendaan debitur itu, menjadi jaminan utang bagi semua kreditor yang memberi pinjaman kepada debitur;

b) hak setiap kreditor atas hasil penjualan seluruh harta kekayaan debitur, merujuk kepada Pasal 1136 KUH Perdata:

(1) dibagi berdasarkan keseimbangan sesuai dengan asas proporsionalitas; menurut besar kecilnya piutang masing-masing secara pari passu berdasarkan prinsip pro rata secara adil;
(2) tidak ada yang didahulukan dan diutamakan di antara para kreditor;

c) kecuali jika kreditornya terdiri dari seorang saja, barulah kreditor tersebut dapat memonopoli seluruh hasil penjualan, apabila hasil penjualan itu mencukupi melunasi pembayaran seluruh utang.

b. Berdasarkan Pasal 1132 KUH Perdata, Kebendaan itu Menjadi Jaminan Bersama bagi semua Kreditor

Meskipun semua benda atau harta kekayaan debitur menurut Pasal 1131 KUH Perdata menjadi tanggungan untuk segala perikatan yang dibuat debitur:

1) namun kepada kreditor tidak diberikan hak preferen dan separatis,

2) tetapi hanya berkedudukan sebagai kreditor "konkuren" bersama-sama dengan kreditor lain, dan

3) masing-masing mereka mendapat pembagian yang seimbang (pro rata) dari hasil penjualan benda debitur tersebut sesuai dengan besar kecilnya masing-masing sesuai asas pari pasu.

Tentang cara pemenuhan yang berbasis sistem pro rata (fond-fond gewijs) ini ditegaskan lagi pada Pasal 1136 KUH Perdata, yang berbunyi:

Semua orang berpiutang yang tingkatnya sama, dibayar menurut keseimbangan.

Dapat dilihat, adanya risiko yang dihadapi kreditor yang tidak dilindungi dengan jaminan yang bersifat preferen. Apabila pada saat yang bersamaan 
terdapat beberapa orang kreditor terhadap seorang debitur, pemenuhan pengembalian uang yang akan diterima sebagai kreditor konkuren hanya sebesar yang seimbang dengan jumlah utang.

3. Cara Pemenuhan, Melalui Proses Litigasi

Apabila debitur cedera janji atau wanprestasi, sedangkan transaksi kredit tidak diikat secara asesor dengan perjanjian jaminan barang tertentu, sehingga jaminan pemenuhannya tunduk kepada ketentuan Pasal 1131 KUH Perdata, cara pemenuhan yang dapat ditempuh dan diupayakan kreditor.

a. Mengajukan Gugatan Perdata ke Pengadilan Negeri

Jika upaya kompromi atau damai maupun strukturasi debitur tetap tidak mau memperbaiki kelalaiannya, jalan satusatunya yang dapat ditempuh ialah "proses litigasi"; menggugat debitur untuk memenuhi pelaksanaan kewajibannya melalui pengadilan, atau melalui arbitrase apabila dalam perjanjian kredit disepakati sengketa yang timbul dari perjanjian diselesaikan oleh badan arbitrase.

b. Meminta Sita Jaminan Atas Harta Kekayaan Debitur

Agar tuntutan lebih efektif dan tidak pampa (illusoir), kreditor dapat meminta kepada PN agar terhadap harta kekayaan debitur diletakkan sita jaminan (Conservatoir Beslag = CB).

Dasar hukum CB: Pasal 227 ayat (1) RBG, Pasal 720 Rv:

1) Membolehkan penyitaan barang debitur selama belum dijatuhkan putus akhir;

2) Tujuannya agar barang tersebut tidak digelapkan atau tidak dihilangkan debitur, selama proses persidangan berlangsung;

3) Dengan demikian, pada saat putusan dilaksanakan, pelunasan pembayaran utang yang dituntut dapat dipenuhi dengan menjual lelang (execuloria verkoop) barang sitaan itu.

Bertitik tolak dari Pasal 227 ayat (1) HIR, Pasal 261 ayat (1) RBG, CS diterapkan dalam perkara utang-piutang:

a) yang timbul dari wanprestasi berdasarkan Pasal 1243 jo. 1246 KUH Perdata dalam bentuk tuntutan:

(a) pengembalian utang pokok,

(b) bunga,

(c) biaya, dan

(d) keuntungan yang akan diperoleh.

b) tetapi dikembangkan juga atas tuntutan yang timbul dari perbuatan melawan hukum (PMH) berdasarkan Pasal 1365 KUH Perdata dalam bentuk tuntutan:

- ganti rugi materiil (actual loss);

- ganti rugi imateriil (ideal loss).

Objek CB dalam Unsecured Debt

a) meliputi seluruh harta kekayaan debitur berdasarkan Pasal 1131 KUH Perdata:

- baik barang bergerak; dan

- barang tidak bergerak;

b) didahulukan CB atas barang bergerak;

c) bila belum cukup, barn dibenarkan CB atas barang tidak bergerak.

Apabila debitor wanprestasi sedangkan transaksi kredit tidak diikat secara asesor dengan perjanjian jaminan barang tertentu, sehingga jaminan pemenuhannya tunduk kepada ketentuan Pasal 1131 KUH Perdata, cara pemenuhan yang ditempuh dan diupayakan kreditor. Jika upaya kompromi atau damai tidak 
tercapai dan debitor tetap tidak mau memperbaiki kelalaiannya, jalan satusatunya yang dapat ditempuh dengan menggugat debitor memenuhi pelaksanaan kewajibannya melalui pengadilan. Terhadap gugatan tersebut, agar tuntutan lebih efektif dan tidak hampa, maka kreditor dapat meminta Pengadilan Negeri agar terhadap harta kekayaan debitor diletakkan sita jaminan (conservatoir beslag).

Wanprestasi berhubungan erat dengan adanya perikatan atau perjanjian antara pihak. Baik perikatan itu didasarkan atas perjanjian sesuai Pasal 1338 KUH Perdata sampai dengan Pasal 1341 KUH Perdata maupun perjanjian yang bersumber pada undang-undang seperti diatur dalam Pasal $1352 \mathrm{KUH}$ Perdata sampai dengan Pasal $1380 \mathrm{KUH}$ Perdata. Apabila salah satu pihak wanprestasi, maka itu menjadi alasan bagi pihak lainnya untuk mengajukan gugatan. Demikian juga tidak terpenuhinya ketentuan Pasal 1320 KUH Perdata tentang syarat-syarat sahnya suatu perjanjian menjadi alasan untuk batal atau dapat dibatalkan suatu persetujuan/perjanjian melalui gugatan. Salah satu alasan untuk mengajukan gugatan ke Pengadilan adalah karena adanya wanprestasi dari debitor. Pasal 1234 KUH Perdata mengatakan bahwa tiap-tiap perikatan adalah untuk memberi sesuatu berbuat sesuatu atau tidak berbuat sesuatu. Wanprestasi itu dapat berupa tidak memenuhi kewajiban sama sekali atau terlambat memenuhi kewajiban, atau memenuhi kewajibannya, tetapi tidak seperti apa yang telah diperjanjikan. ${ }^{9}$

Pasal 1239 KUH Perdata mengatakan bahwa apabila ada wanprestasi berupa berbuat sesuatu, tidak berbuat sesuatu, maka debitor dapat digugat tentang penggantian biaya kerugian yang timbul dan diderita oleh kreditor dan membayar bunga. Wanprestasi itu dapat berupa:

1. Tidak memenuhi prestasi sama sekali.

2. Terlambat memenuhi prestasi; dan

3. Memenuhi prestasi secara salah/tidak baik.

Menurut Pasal 1266 KUH Perdata jika terjadi wanprestasi yang menimbulkan kerugian bagi kreditor maka kreditor dapat menuntut, yaitu:

1. Pemenuhan perikatan,

2. Pemenuhan perikatan dengan ganti rugi

3. Ganti rugi:

4. Pembatalan persetujuan timbal balik,

5. Pembatalan dengan ganti rugi.

Rangkaian proses pemeriksaan persidangan harus berjalan menurut tata cara yang ditentukan oleh peraturan perundang-undangan. Pemeriksaan persidangan pada tingkat pertama di Pengadilan Negeri (PN), tingkat banding di Pengadilan Tinggi (PT), dan tingkat kasasi di Mahkamah Agung (MA) di awali dengan proses pemanggilan (atau biasa disebut dengan panggilan) dan pemberitahuan. Pemanggilan terhadap tergugat harus dilakukan secara patut. Setelah melakukan panggilan, juru sita harus menyerahkan risalah (relaas) panggilan kepada hakim yang akan

9 R. Subekti, Pokok-Pokok Hukum Perdata, Penerbit Pt. Intermasa, Jakarta, 1980, hal. 147 
memeriksa perkara tersebut yang merupakan bukti bahwa tergugat telah dipanggil. 10

Tujuan pemanggilan yaitu penyampaian pesan atau informasi kepada seseorang agar dia tahu tentang segala sesuatu hal yang hendak dilakukan oleh pihak lawan maupun suatu tindakan yang akan dilakukan pengadilan. ${ }^{11}$ Berdasarkan uraian tersebut, dapat diartikan bahwa ruang lingkup tujuan pemanggilan meliputi juga pemberitahuan. Dengan demikian, oleh karena arti dan cakupan panggilan meliputi pemberitahuan, segala syarat dan tata cara yang ditentukan undang-undang mengenai tindakan hukum pemanggilan, sama dan berlaku sepenuhnya dalam pemberitahuan. ${ }^{12}$

Pemanggilan atau panggilan (convocation, convocatie) dalam arti sempit dan sehari-hari sering diidentikkan hanya terbatas pada perintah menghadiri sidang pada hari yang ditentukan. Akan tetapi, dalam hukum acara perdata, sebagaimana dijelaskan dalam Pasal 388 HIR, pengertian panggilan meliputi makna dan cakupan yang lebih luas, yaitu: ${ }^{13}$

a. Panggilan sidang pertama kepada penggugat dan tergugat;

b. Panggilan menghadiri sidang lanjutan kepada pihak-pihak atau salah satu pihak apabila sidang yang lalu tidak hadir baik tanpa alasan yang sah atau berdasarkan alasan yang sah;

c. Panggilan terhadap saksi yang diperlukan atas permintaan salah satu pihak berdasarkan Pasal 139 HIR

10 Sudikno Mertokusumo, Hukum Acara Perdata. (Yogyakarta: Liberty. 2002). hlm. 98.

${ }^{11}$ Op. Cit, hlm 214

${ }^{12}$ Ibid, hlm. 212

${ }^{13}$ Ibid, hlm. 213 (dalam hal mereka tidak dapat menghadirkan saksi yang penting ke persidangan);

d. Selain daripada itu, panggilan dalam arti luas, meliputi juga tindakan hukum pemberitahuan atau aanzegging (notification), yaitu:

1) Pemberitahuan putusan Pengadilan Tinggi dan Mahkamah Agung;

2) Pemberitahuan permintaan banding kepada terbanding;

3) Pemberitahuan memori banding dan kontra memori banding;

4) Pemberitahuan permintaan kasasi dan memori kasasi kepada termohon kasasi;

Panggilan terhadap para pihak untuk menghadiri sidang dilakukan oleh juru sita atau juru sita pengganti di tempat tinggal atau tempat kediaman yang dipanggil atau tempat kedudukannya. ${ }^{14}$

Juru sita adalah petugas yang ditugaskan oleh majelis pengadilan yang mempunyai kewajiban menjalankan pemberitahuan dan semua surat-surat yang lain atau juga menjalankan perintah hakim dengan segala keputusannya. ${ }^{15}$ Prof. Dr. Sudikno Mertokusumo, S.H. dalam bukunya juga menyatakan bahwa pemanggilan dilakukan oleh juru sita yang menyerahkan surat panggilan (exploit) beserta salinan gugat kepada tergugat pribadi di tempat tinggalnya. ${ }^{16} \mathrm{Hal}$ ini sebagaimana diatur dalam Pasal 388 ayat (1) jo. Pasal 390 ayat (1) HIR yang

14 Keputusan Ketua Mahkamah Agung Republik Indonesia Nomor : KMA/032/SK/IV/2006 angka ke-2 huruf $\mathrm{C}$.

15 Yan Pramadya Puspa, Kamus Hukum, Edisi Lengkap. Bahasa Belanda Indonesia Inggris, (Semarang: Aneka Ilmu, 1977), hlm. 254.

16 Sudikno Mertokusumo. Hukum Accra Perdata.(Yogyakarta: Liberty, 2002), hlm. 97. 
berbunyi sebagai berikut:

Berdasarkan ketentuan yang diatur dalam pasal-pasal tersebut, dapat ditarik kesimpulan sebagai berikut:

a. Pemanggilan dilakukan oleh juru sita sesuai dengan kewenangan relatif yang dimilikinya.

b. Jika orang yang hendak dipanggil berada di luar yuridiksi relatif yang dimilikinya, pemanggilan dilakukan berdasarkan ketentuan Pasal $5 \mathrm{Rv}$, yaitu mendelegasikan pemanggilan kepada juru sita yang berwenang di wilayah hukum tersebut. ${ }^{17}$ Kewenangan atau yuridiksi relatif juru sita mengikuti kewenangan relatif Pengadilan Negeri dimana ia terdaftar sebagai juru sita.

Pasal 5 Rv tersebut berbunyi sebagai berikut:

"Jika tergugat bertempat tinggal di luar wilayah kekuasaan hakim yang menerima gugatan atau segera dalam hal sepeti diuraikan di atas atau atas pilihan penggugat atau atas permohonan pengacaranya dengan surat kepada hakim di tempat tinggal tergugat yang kemudian akan memberitahukannya dengan perantara juru sita yang ditunjuknya, jika tergugat bertempat tinggal di dalam karesidenan tempat akan diadakan sidang majelis, dan jika tidak tinggal disitu ia akan mengirim surat kepada asisten residen yang mempunyai wilayah tempat tinggal

Yahya Harahap. Hukum Acara Perdata Pembuktiangatan, Persidangan, Penyitaan. Grafika, 2005), hlm. 219.

tergugat.

Panggilan yang sah dan resmi harus dilakukan oleh juru sita. Pelaksanaan panggilan oleh juru sita merupakan salah satu syarat agar panggilan dapat dinyatakan sebagai panggilan yang sah dan resmi.

Pasal 121 ayat (1) HIR berbunyi sebagai berikut:

Sesudah surat gugat yang dimasukkan itu atau catatan yang diperbuat itu dituliskan oleh panitera dalam daftar yang disediakan untuk itu, maka ketua menentukan hari dan jamnya perkara itu akan diperiksa di muka pengadilan negeri, dan ia memerintahkan memanggil kedua belah pihak supaya hadir pada waktu itu, disertai oleh saksi-saksi yang dikehendakinya untuk diperiksa, dan dengan membawa segala surat-surat keterangan yang hendak dipergunakannya.

Berdasarkan Pasal 121 ayat (1) HIR tersebut, kewenangan yang dimiliki juru sita ini diperoleh melalui perintah ketua majelis hakim yang dituangkan dalam penetapan hari sidang atau penetapan pemberitahuan. Kewenangan yang dimiliki juru sita dalam melakukan pemanggilan terbatas pada wilayah kewenangan relatif pengadilan tempat ia bertugas. Oleh karena itu, apabila orang yang hendak dipanggil berada di luar kewenangan relatif juru sita, maka juru sita tersebut harus mendelegasikan kewenangannya itu kepada juru sita pengadilan di mana orang yang hendak dipanggil berada.

Pengertian

pemanggilan adalah

pendelegasian

melimpahkan pelaksanaan pemanggilan 
kepada juru sita pada pengadilan negeri yang lain. ${ }^{18}$ Misalnya tergugat bertempat tinggal di wilayah Bogor, sedangkan perkara nya disidangkan di Pengadilan Negeri Jakarta Selatan, maka juru sita Pengadilan Negeri Jakarta Selatan yang hendak melakukan pemanggilan harus mendelegasikan wewenangnya tersebut kepada juru sita Pengadilan Negeri Bogor.

Dalam hal seperti ini, juru sita Pengadilan Negeri Jakarta Selatan tidak berwenang menyampaikan panggilan karena orang yang hendak dipanggil berada dalam kewenangan relatif Pengadilan Negeri Bogor. Dengan demikian, yang berwenang melakukan panggilan adalah juru sita Pengadilan Negeri Bogor.

Ketentuan yang mengatur mengenai pendelegasian wewenang untuk melakukan pemanggilan diatur dalam Pasal 5 Rv. Penerapan yang diatur dalam pasal tersebut adalah sebagai berikut:

1. Orang yang hendak dipanggil berada di luar wilayah hukum atau kewenangan relatif pengadilan negeri tempat juru sita bertugas.

2. Pemanggilan dilaksanakan oleh juru sita pengadilan negeri yang meliputi wilayah hukum tempat tinggal orang yang hendak dipanggil.

3. Ketua pengadilan negeri yang bersangkutan meminta bantuan kepada ketua pengadilan negeri yang membawahi wilayah hukum tempat tinggal tergugat untuk memerintahkan juru sita pengadilan negeri tersebut menyampaikan pemanggilan.

4. Ketua pengadilan yang dimintai

\footnotetext{
${ }^{18}$ Ibid, hlm. 225
}

bantuan mengeluarkan perintah pemanggilan kepada juru sita berdasarkan permintaan bantuan yang dimaksud.

5. Segera setelah itu, menyampaikan langsung kepada ketua pengadilan negeri yang melimpahkan tentang pelaksanaan pemanggilan yang dilakukan.

Berdasarkan Pasal 390 ayat (1) HIR dan Pasal 2 ayat (3) Rv, panggilan harus dilakukan dalam bentuk surat tertulis. Surat tertulis ini lazim disebut dengan surat panggilan atau relaas (bericht, report) panggilan maupun berita acara panggilan. ${ }^{19}$ Panggilan yang disampaikan dalam bentuk lisan tidak dibenarkan karena sulit untuk membuktikan keabsahannya sehingga dapat merugikan pihak yang dipanggil. Oleh karena itu panggilan dalam bentuk lisan tidak sah menurut hukum. ${ }^{20}$ Ruang lingkup pengertian pemanggilan dalam bentuk tertulis diatur dalam Pasal 2 ayat (3) Rv. Pasal ini mengatur bahwa pemanggilan dalam bentuk tertulis berupa telegram dan surat tercatat dapat dibenarkan dan dianggap sebagai panggilan atau pemberitahuan yang patut (properly). Bunyi pasal tersebut yaitu sebagai berikut: "Pemberitahuan dengan surat tercatat antara lain berlaku sebagai pemberitahuan yang patut. Pemberitahuan dilaksanakan atas biaya yang berkepentingan. Pegawai negeri yang menerima pemberitahuan tidak berkewajiban melaporkan atau memberi penjelasan lebih lanjut

19 Subakti, Hukum Acara Perdata, (Jakarta: Bina Cipta, 1977), hlm. 5

${ }^{20}$ Op. Cit., hlm. 384 
Jamillah, Pelaksanaan Pasal 1131 KUHPerdata atas Jaminan Benda Milik Debitur

tentang hal itu selama yang berkepentingan belum mengganti biayanya."

Ketentuan yang mengatur isi surat panggilan diatur dalam Pasal 121 ayat (1) dan (2) HIR serta Pasal 1 Rv. Bunyi pasal tersebut yaitu sebagai berikut:

Berdasarkan ketentuan tersebut dapat ditarik kesimpulan bahwa hal-hal yang harus dicantumkan dalam isi surat panggilan, yaitu:

a. Nama yang dipangil:

b. Hari dan jam serta tempat sidang;

c. Membawa saksi-saksi yang diperlukan;

d. Membawa segala surat-surat yang hendak digunakan, dan

e. Penegasan dapat menjawab gugatan dengan surat;

f. Melampiri surat panggilan dengan salinan surat gugatan, surat panggilan kepada tergugat untuk sidang pertama harus menyebutkan penyerahan sehelai salinan surat gugatan dan pemberitahuan kepada pihak tergugat, bahwa ia boleh mengajukan jawaban tertulis yang diajukan dalam sidang. ${ }^{21}$

g. Salinan tersebut dianggap gugatan asli

Hal-hal yang menjadi isi surat panggilan tersebut bersifat kumulatif dan imperatif. Artinya, lima hal yang menjadi isi surat panggilan tersebut harus terpenuhi semuanya. Apabila salah satunya saja ticlak terpenuhi maka surat panggilan tersebut menjadi carat hukum dan dianggap tidak sah. Akan tetapi, dalam rangka menjalankan sistem peradilan yang

21 Keputusan Ketua Mahkamah Agung Republik Indonesia Nomor : KMA/032/SK/IV/2006 angka ke-2 huruf $\mathrm{C}$. cepat, sederhana, dan biaya ringan maka kesalahan atau kelalaian dalam mencantumkan isi selain mengenai nama pihak yang clipanggil, hari, dan tempat persidangan masih dapat diberikan ditoleransi. Dengan demikian, kesalahan atau kelalaian seperti itu tidak mengakibatkan panggilan tidak sah.

Selain itu, surat panggilan juga harus memenuhi beberapa persyaratan agar dapat dikatakan sebagai surat panggilan yang sah secara otentik. Persyaratan-persyaratan yang harus dipenuhi tersebut yaitu:

a. Ditandatangani oleh juru sita Apabila sudah ditandangani dengan sendirinya menurut hukum sah sebagai akta otentik yang dibuat oleh pejabat juru sita. Akta otentik ini hanya dapat digugurkan jika ada suatu putusan pidana pemalsuan Surat yang telah berkekuatan hukum tetap dari pengadilan yang menyatakan isi atau tanda tangan yang tercantum di dalamnya adalah palsu.

b. Berisi keterangan yang diulis tangan juru sita yang menjelaskan panggilan telah disampikan di tempat tinggal yang bersangkutan secara in person, atau kepada keluarga, atau kepada kepala desa, atau lurah disertai dengan tanda tangan orang yang menerima panggilan tersebut.

Tata cara pemanggilan menurut menurut hukum diatur dalam Pasal 390 ayat (1) dan (2) dan (3) HIR ${ }^{22}$, Pasal 1, Pasal 6, angka ke-7 dan ke-8, serta Pasal 7

22 M. Karjadi. Reglemen Indonesia yang Diperbaharui, S 1941 No. 44, RIB (HIR). (Bogor; Politeia. 1991), hlm. 95 
Rv. ${ }^{23}$ Pasal-pasal tersebut mengklasifikasi tata cara pemanggilan berdasarkan diketahui atau tidak diketahuinya tempat tinggal tergugat atau orang yang dipanggil, pemanggilan tergugat yang berada di luar negeri, dan pemanggilan terhadap yang telah meninggal dunia.

Ruang lingkup pengertian tempat tinggal seseorang meliputi: ${ }^{24}$
a. Tempat kediaman, atau
b. Tempat alamat tertentu, atau
c. Tempat kediaman sebenarnya

Yang dimaksud kediaman sebenarnya atau sebenarnya berdiam adalah tempat secara nyata tinggal. ${ }^{25}$ Yang sah dan resmi dijadikan sumber menentukan tempat tinggal tergugat dari beberapa jenis akta atau dokumen. Yang terpenting diantaranya: 26
a. Berdasarkan KTP,
b. Kartu rumah tangga atau kartu keluarga,
c. Surat pajak, dan
d. Anggaran dasar perseroan.

Ketentuan yang mengatur jarak waktu antara pemanggilan dengan hari sidang yaitu:

Pasal 122 HIR $^{27}$ dan Pasal 10 RV. ${ }^{28}$ Menurut ketentuan tersebut, hal-hal yang mempengaruhi dalam menentukan jarak waktu antara pemanggilan dengan hari sidang yaitu:

a. Faktor jarak antara tempat tinggal

23 Engelbercht, Himpunan Peraturan Perundang-Undangan Menurut Sistem Engelbrecht, Buku I, Tata Negara, Perdata, Dagang, Pidana, (Jakarta: Ichtiar Baru Van Hoeve, 2007), hlm. 671 dan 673

\footnotetext{
${ }^{24}$ Yahya Harahap. Op. Cit., hlm. 192.

${ }^{25} \mathrm{Ibid}$

${ }^{26} \mathrm{Ibid}$

${ }^{27}$ Op. Cit., hlm. 35

${ }^{28}$ Op. Cit., hlm. 674
}

tergugat dengan gedung tempat sidang dilangsungkan. Pasal $10 \mathrm{Rv}$ mengatur hal tersebut sebagai berikut:

1. Apabila jarak antara tempat tinggal tergugat dengan gedung pengadilan negeri tempat sidang tidak jauh, jarak waktu antara pemanggilan dengan hari sidang adalah 8 (delapan) hari.

2. Apabila jarak waktu antara tempat tinggal tergugat dengan gedung pengadilan negeri tempat sidang agak jauh, jarak waktu antara pemanggilan dengan hari sidang adalah 14 (empat belas) hari.

3. Apabila jarak antara tempat tinggal tergugat dengan gedung pengadilan negeri tempat sidang jauh, jarak waktu antara pemanggilan dengan hari sidang adalah 20 (dua puluh) hari.

Mengenai definisi tidak jauh, agak jauh, dan jauh, ketentuan Pasal 10 Rv tidak menjelaskannya lebih jauh.

b. Jarak waktu pemanggilan, dengan hari sidang dalam keadaan yang mendesak diatur dalam Pasal 122 HIR, Pasal tersebut menentukan bahwa jarak waktu pemanggilan dalam keadaan mendesak dapat dipersingkat dengan syarat tidak boleh kurang dari 3 (tiga) hari. Definisi keadaan mendesak dalam hal ini yaitu tergugat dalam keadaan perlu benar tidak dijelaskan oleh undang-undang. ${ }^{29}$ Penilaian mengenai keadaan yang mendesak sepenuhnya berdasarkan pertimbangan hakim dengan didasari alasan yang objektif.

c. Jarak waktu pemanggilan dengan hari

\footnotetext{
${ }^{29}$ Yahya Harahap, Op. Cit., hlm. 192
} 
Jamillah, Pelaksanaan Pasal 1131 KUHPerdata atas Jaminan Benda Milik Debitur

sidang terhadap orang yang berada di luar negeri. Prinsipnya didasarkan pada perkiraan yang wajar dengan mempertimbangkan faktor jarak negara tempat tinggal tergugat dengan Indonesia pada satu segi dan jarak tempat tinggal tergugat dengan Konsulat Jenderal Republik Indonesia serta faktor birokrasi yang harus ditempuh dalam penyampaian panggilan. ${ }^{30}$

d. Jarak waktu pemanggilan dengan hari sidang apabila tergugat terdiri dari beberapa orang. Penentuan jarak waktu pemanggilan dengan hari sidang dalam hal tergugat terdiri dari beberapa orang tidak diatur dalam HIR, tetapi diatur dalam Pasal $14 \mathrm{Rv}$. Bunyi pasal tersebut yaitu sebagai berikut:

"Jika beberapa orang karena gugatan yang sama ditetapkan untuk jangka waktu yang berlainan, maka semua akan ditetapkan untuk datang menghadap pada waktu yang ditentukan untuk yang bertempat tinggal terjauh."

Pada Pasal 6 Undang-Undang Hak Tanggungan No. 4 Tahun 1996, berbunyi:

"Apabila debitor cidera janji, pemegang hak tanggungan pertama mempunyai hak untuk menjual objek Hak Tanggungan atas kekuasaan sendiri melalui pelelangan umum serta mengambil pelunasan piutangnya dari hasil penjualan tersebut."

Dalam akta pemberian Hak Tanggungan telah disepakati janji-jani sebagaimana yang dimaksud pada Pasal

${ }^{30}$ Ibid, hlm. 192
11 ayat 2 Undang-undang Hak Tanggungan No. 4 Tahun 1996, termasuk tetapi tidak terbatas pada janji bahwa TERGUGAT I sebagai Pemegang Hak Tanggungan Pertama mempunyai hak untuk menjual atas kekuasaan sendiri obyek Hak Tanggungan jika PENGGUGAT ingkar janji/wanprestasi. ${ }^{31}$

Pasal 11 ayat 2 Undang-Undang Hak Tanggungan NO. 4 Tahun 1996, berbunyi:

'Janji bahwa pemegang hak tanggungan pertma mempunyai hak untuk menjual atas kekuasaan sendiri obyek Hak Tanggungan apabila debitor cidera janji

Menurut Kaedah hukum, Vide Pasal 14 Undang-Undang Hak Tanggungan No. 4 Tahun 1996, Sertifikat Hak Tanggungan yang memuat irah-irah "Demi Keadilan Berdasarkan Ketuhanan Yang Maha Esa" mempunyai kekuatan eksekutorial yang sama dengan putusan Pengadilan yang telah berkekuatan hukum tetap dan berlaku sebagai pengganti Grose Akta Hipotik ex Pasal 224 HIR. ${ }^{32}$

Pasal 14 UU Undang-undang Hak Tanggungan No. 4 Tahun 1996 berbunyi:

(3) Sertipikat Hak Tanggungan sebagaimana dimaksud pada ayat (2) mempunyai kekuatan eksekutorial yang sama dengan putusan pengadilan yang telah memperoleh kekuatan hukum tetap dan berlaku sebagai pengganti grosse acte Hypotheek sepanjang mengenai hak atas tanah.

Dalam hal seseorang mengajukan gugatan kepada Pengadilan Negeri, bukan

31 Keputusan Hakim Pengadilan Negeri Medan Nomor : 235/Pdt.G/2013/PN.Mdn angka ke-20

${ }^{32}$ Ibid, angka ke-21 
saja ia mengharapkan agar memperoleh putusan yang menguntungkan baginya, namun pula bahwa putusan tersebut akhirnya dapat dilaksanakan.

Suatu putusan di mana penggugat telah dimenangkan, akan tetapi sewaktu diadakan pelaksanaan atas putusan tersebut ternyata barang yang dipersengketakan sudah tidak ditangan pihak yang dikalahkan, atau dalam hal menyangkut suatu pembayaran sejumlah Utang ternyata pihak yang dikalahkan sewaktu pelaksanaan putusan dilakukan ia sudah tidak mempunyai sesuatu barang di rumahnya, menjadi tidak berfaedah sama sekali bagi penggugat.

Oleh karena hukum acara perdata memungkinkan bagi orang yang sudah dikalahkan oleh putusan Pengadilan Negeri untuk naik banding, dan setelah itu kemudian dilanjutkan lagi dengan mengajukan permohonan kasasi, pada azasnya putusan tidak dilaksanakan menunggu sampai ada putusan dari Mahkamah Agung, mengakibatkan proses mana dapat berjalan bertahun-tahun. Mengingat, hal itu, apabila tidak dikenal adanya lembaga sita jaminan, bagi penggugat yang telah dimenangkan perkaranya pada akhirnya merupakan pihak yang "kalah". Karena selama proses berlangsung ia telah mengeluarkan banyak biaya perkara, sedangkan apa yang ia tuju tidak memperoleh hasil, bahkan biaya perkara yang ia telah keluarkan selama ini juga tidak diganti.

Oleh karena itu untuk mengatasi permasalahan tersebut maka hukum acara perdata mengenal adanya lembaga sita jaminan.

1. Pengertian, Penerapan dan Tujuan Penyitaan a. Menyita Milik Tergugat untuk Menjamin Pembayaran Utang Sita conservatoir diatur dalam Pasal 261 RBg, yang berbunyi:

1) Jika ada sangka yang beralasan, bahwa orang yang berutang sebelum dijatuhkan keputusan kepadanya, atau sedang keputusan yang dijatuhkan kepadanya, belum dapat dijalankan, jalankan, berusaha akan menggelapkan atau mengangkut barangnya, baik yang tidak tetap, baik yang tetap, dengan maksud akan menjauhkan barang itu dari penagih utang, maka Ketua, atas surat permintaan yang dimasukkan untuk itu, oleh orang yang berkepentingan dapat memberi perintah supaya barang itu disita akan menjaga hak orang yang meminta itu dan kepadanya hendaklah diberitahukan, bahwa ia akan menghadap persidangan pertama yang akan datang dari Pengadilan Negeri untuk memajukan gugatannya dan meneguhkannya.

2) Atas perintah Ketua orang yang berutang hendaklah dipanggil menghadap persidangan itu juga.

3) Mengenai orang yang harus menjalankan penyitaan itu serta peraturan-peraturan yang akan dituruti dalam hal itu dan akibat yang berhubung dengan itu Pasal 212, 213, 214 RBg masih berlaku.

4) Pada hari pemeriksaan perkara, maka pemeriksaan perkara itu dilakukan secara yang biasa. Kalau gugatan diterima, maka penyitaan disahkan, kalau ditolak, maka diperintahkan supaya penyitaan dicabut.

5) Hal mencabut penyitaan itu, biar 
Jamillah, Pelaksanaan Pasal 1131 KUHPerdata atas Jaminan Benda Milik Debitur

apapun juga boleh diminta kalau diadakan jaminan atau tanggungan lain yang cukup. ${ }^{33}$

Menurut ketentuan yang termuat dalam Pasal $261 \mathrm{RBg}$, perihal sita conservatoir dapat dimohonkan oleh penggugat "sebelum dijatuhkan putusan" atau sudah ada putusan, akan tetapi putusan tersebut belum dapat dijalankan".

Dalam praktek permohonan akan sita jaminan dilakukan dalam surat gugatan dan dalam petitum dimohonkan pernyataan sah dan berharga atau sita jaminan tersebut dengan kata lain perkataan permohonan tersebut diajukan "sebelum dijatuhkan putusan. ${ }^{34}$

Bertitik tolak dari penggarisan Pasal $261 \mathrm{RBg}$, penerapan sitajaminan pada dasarnya hanya terbatas pada sengketa perkara Utang-piutang yang ditimbulkan oleh wanprestasi. Dengan diletakkannya sita pada barang milik tergugat, barang itu tidak dapat dialihkan tergugat kepada pihak ketiga, sehingga tetap utuh sampai putusan berkekuatan hukum tetap.

Apabila tergugat tidak memenuhi pembayaran secara sukarela. Pelunasan utang atau ganti rugi itu, diambil secara paksa dari barang sitaan melalui penjualan lelang. Dengan demikian, tindakan penyitaan barang milik tergugat sebagai debitur:

1) bukan untuk diserahkan dan dimiliki penggugat (pemohon sita),

33 Retnowulan Sutantio dan Iskandar Oeripkartawinata, Hukum Acara Perdata dalam Teori dan Praktek, Penerbit Mandar Maju, Bandung, 1997, hal. 99-100

${ }^{34}$ M. Yahya Harahap, Op. Cit, hal. 282-283
2) tetapi diperuntukkan melunasi pembayaran utang tergugat kepada penggugat.

b. Dapat Diterapkan atas Tuntutan Ganti Rugi

Dalam arti sempit berdasarkan Pasal 261 RBg, sita jaminan hanya dapat diterapkan dalam perkara utang piutang. Akan tetapi dalam praktek, penerapannya diperluas meliputi sengketa tuntutan ganti rugi baik yang timbul dari:

1) wanprestasi berdasarkan Pasal 1243 KUH Perdata Jo. Pasal 1247 KUH Perdata dalam bentuk penggantian biaya, bunga dan keuntungan yang akan diperoleh, atau

2) $\mathrm{PMH}$ berdasarkan Pasal $1365 \mathrm{KUH}$ Perdata, dalam bentuk ganti rugi materil dan immateril

Untuk menjamin pemenuhan pembayaran tuntutan ganti rugi yang diajukan penggugat berdasarkan wanprestasi atau $\mathrm{PMH}$, dapat meminta kepada pengadilan agar diletakkan sita jaminan terhadap barang milik tergugat. Dengan demikian, praktek peradilan telah memperluas penatsiran Utang meliputi ganti rugi, sehingga terhadap sengketa yang demikian dapat dibenarkan untuk menerapkan sita jaminan yang diatur Pasal 227 ayat (1) HIR atau Pasal 720 Rv. Perluasan penerapan tersebut merupakan elemen pokok tuntutan utang, pada dasarnya sama dengan tuntutan ganti rugi. Sama-sama berbentuk pemenuhan pembayaran prestasi berupa uang kepada penggugat.

c. Tujuan Penyitaan 
1) Agar gugatan tidak illusoir

Tujuan utama penyitaan, agar barang kekayaan tergugat:

a) Tidak dipindahkan kepada orang lain melalui jual beli atau penghibahan, dan sebagainya.

b) Tidak dibebani dengan sewa menyewa atau diagunkan kepada pihak ketiga.

Maksudnya menjaga keutuhan dan keberadaan harta kekayaan tergugat tetap utuh seperti semula, secara proses penyelesaian perkara berlangsung, agar pada saat putusan memperoleh kekuatan hukum yang tetap, barang yang disengketakan dapat diserahkan dengan sempurna kepada penggugat. Atau apabila perkara yang disengketakan mengenai tuntutan pembayaran sejumlah uang, harta yang disita tetap utuh sampai putusan berkekuatan hukum tetap sehingga apabila tergugat tidak melaksanakan pemenuhan pembayaran secara sukarela, pemenuhan dapat diambil dari barang harta kekayaan tergugat dengan jalan menjual lelang (executorial verkoop) barang yang disita tersebut. Tujuan utama sita agar gugatan penggugat tidak illusoir atau tidak hampa pada saat putusan dilaksanakan. Ditinjau dari segi teknis peradilan, penyitaan atau beslag:

(a) merupakan upaya hukum bagi penggugat untuk menjamin dan melindungi kepentingannya atas keutuhan dan keberadaan harta kekayaan tergugat sampai putusan memperoleh kekuatan hukum tetap.

(b) upaya itu bermaksud untuk menghindari tindakan itikad buruk tergugat dengan berusaha melepaskan diri memenuhi tanggung jawab perdata yang harus dipikulnya atas $\mathrm{PMH}$ atau wanprestasi yang dilakukannya.

(c) dengan adanya putusan penyitaan melalui perintah pengadilan, secara hukum harta kekayaan tergugat berada dan ditempatkan dibawah penjagaan dan pengawasan pengadilan, sampai ada perintah pengangkatan atau pencabutan sita.

(d) apabila penyitaan telah diumumkan melalui pendaftaran pada buku register kantor yang berwenang untuk itu sesuai dengan Pasal 213 RBg, pada tindakan itu melekat ketentuan berikut:

a). Larangan Pasal 215 RBg

Melarang tergugat menjual, menghibahkan, atau memindahkan barang itu dalam bentuk apapun dan kepada siapapun.

b). Pelanggaran atas larangan itu, menimbulkan dua sisi akibat hukum:

(1) Akibat hukum dari segi perdata:

- jual beli atau pemindahan batal demi hukum

- oleh karena itu status barang kembali kepada keadaan semula (status quo) sebagai barang sitaan, dan pemindahan dianggap tidak pernah terjadi.

(2) Akibat hukum dari segi pidana: 
Jamillah, Pelaksanaan Pasal 1131 KUHPerdata atas Jaminan Benda Milik Debitur

$\begin{array}{lr}\text { - dapat } & \text { diancam } \\ \text { melakukan } & \text { tindak } \\ \text { pidana Pasal } & 231 \text { KUH } \\ \text { Pidana berupa kejahatan } \\ \text { dengan } & \text { sengaja } \\ \text { melepaskan barang yang } \\ \text { telah disita } & \text { menurut } \\ \text { peraturan } & \text { undang- } \\ \text { undang yang berlaku. } \\ \text { - perbuatan itu diancam } \\ \text { dengan pidana penjara } \\ \text { maksimal } 4 \text { (empat) } \\ \text { tahun. }\end{array}$

Pada dasarnya ancaman pidana yang diatur dalam Pasal 231 Ayat (1) KUH Pidana ini, meliputi:

(a) melepaskan barang yang disita,

(b) melepaskan barang yang disimpan atas perintah hakim, dan

(c) menyembunyikan barang yang dilepaskan dari sitaan.

Dengan mengaitkan tujuan penyitaan dengan ketentuan Pasal 231 KUH Pidana terjamin perlindungan yang kuat bagi penggugat atas terpenuhinya pelaksanaan putusan pengadilan saat eksekusi dijalankan. Kalau tidak diangkat sita untuk benda yang tidak diperjanjikan berarti dalam hal ini tidak adanya sengketa terhadap harta kekayaan debitor. Surat/keterangan tidak ada silang sengketa dapat dibuktikan dengan membuat surat pernyataan yang diketahui Lurah bahwa tanah tersebut milik debitor tidak dalam keadaan sengketa, tidak dijaminkan. Jika suatu saat tanah tersebut disangkal oleh istri debitor yang lain maka debitor harus membuat Surat pernyataan yang menyatakan hanya memiliki satu orang istri, yang mana surat pernyataan tersebut harus dibubuhi tanda tangan, diberi materai, cap jempol, dan harus dilegalisir oleh notaris.

2) Objek eksekusi sudah pasti

Pada saat permohonan sita diajukan, penggugat harus menjelaskan dan menunjukkan identitas barang yang hendak disita. Menjelaskan letak, jenis, ukuran, dan batas-batasnya. Atas permohonan itu, pengadilan melalui juru sita memeriksa dan meneliti kebenaran identitas barang pada saat penyitaan dilakukan. Bertitik tolak dari permohonan dan pelaksanaan sita, sejak semula sudah diketahui dan pasti objek barang yang disita. Lebih lanjut, hal ini langsung memberi kepastian atas objek eksekusi, apabila putusan telah berkekuatan hukum tetap. Kemenangan penggugat, secara langsung dijamin dengan pasti oleh barang sitaan. Tidak dibutuhkan lagi waktu untuk mencari dan mengetahui dimana harta kekayaan tergugat berada. Barang sitaan langsung mempunyai makna dan nilai materi atas kemenangan penggugat, karena didukung oleh harta kekayaan tergugat yang sudah ditempatkan dibawah penjagaan dan pengawasan pengadilan terhitung sejak sita diletakkan.

Kepastian objek eksekusi atas barang sitaan semakin sempurna sesuai dengan penegasan Mahkamah Agung yang menyatakan, kalau putusan telah berkekuatan hukum tetap maka barang yang disita demi hukum langsung menjadi sita eksekusi. Dengan demikian barang yang disita:

a. dapat langsung diserahkan kepada pihak penggugat, jika perkara yang terjadi mengenai sengketa milik,

b. atau barang yang disita dapat 
langsung dieksekusi melalui penjualan lelang, apabila perkara yang terjadi sengketa utang piutang atau tuntutan ganti rugi berdasarkan wanprestasi atau $\mathrm{PMH}$.

2. Objek Sita Jaminan

Objek sita jaminan dalam perkara utang piutang atau ganti rugi, yaitu:

a. Meliputi Seluruh Harta Kekayaan

Tergugat

Sepanjang utang atau tuntutan ganti rugi tidak dijamin dengan agunan tertentu, sita jaminan dapat diletakkan diatas seluruh harta kekayaan tergugat. Penerapan tersebut bertitik tolak dari Pasal 1131 KUH Perdata jo. Pasal 261 RBg, yang menegaskan :

1) segala kebendaan debitor baik yang bergerak maupun yang tidak bergerak, menjadi tanggungan untuk segala perikatan perseorangan (Pasal $1131 \mathrm{KUH}$ Perdata);

2) barang debitor (tergugat) baik yang bergerak dan tidak bergerak dapat diletakkan sita jaminan untuk pembayaran utangnya atas permintaan kreditor (penggugat).

Akan tetapi, kebolehan menyita seluruh harta milik tergugat dalam sengketa utang atau ganti rugi harus memperhatikan prinsip yang digariskan Pasal $211 \mathrm{RBg}$ :

a. dahulukan penyitaan barang bergerak. Jadi yang pertama-tama disita, barang bergerak. Apabila nilai barang bergerak yang disita mencukupi untuk melunasi jumlah gugatan, penyitaan dihentikan sampai disita saja.

b. Kalau barang yang bergerak tidak mencukupi jumlah tuntutan, baru dibolehkan meletakkan sita jaminan terhadap barang tidak bergerak. Memperhatikan tata tertib penyitaan tersebut, dilarang langsung menyita barang tidak bergerak, jika tergugat memiliki barang bergerak. Namun, apabila sama sekali tidak ada barang bergerak barulah dapat langsung disita barang tidak bergerak.

3. Tata Cara Pelaksanaan Sita Jaminan

Tata cara pelaksanaan sita jaminan terdapat dalam Pasal 261 RBg. Tata caranya tunduk kepada ketentuan yang digariskan Pasal 212 dan 214 RBg. Terhadap objek sita jaminan barang tidak bergerak, sesuai dengan ketentuan Pasal 213 RBg, yaitu mendaftarkan dan mengumumkan berita acara penyitaan di kantor pendaftaran yang berwenang untuk itu. Pokok-pokok dan syarat sita jaminan adalah sebagai berikut:

a. Dilaksanakan berdasarkan penetapan pengadilan:

Ketua Pengadilan Negeri atau majelis yang memeriksa perkara menerbitkan Surat penetapan sita. Apabila pengadilan berpendapat permohonan sita beralasan dan oleh karena itu dapat dikabulkan maka:

- Pengabulan sita dituangkan dalam Surat penetapan.

Surat penetapan, berisi perintah kepada panitera atau juru sita untuk melaksanakan sitaJaminan terhadap harta kekayaan tergugat.

b. Penyitaan Dilaksanakan Panitera atau Juru Sita

c. Memberitahukan penyitaan kepada tergugat yang berisi:

1) Hari, tanggal, bulan, tahun, dan jam serta tempat penyitaan;

2) Agar tergugat menghadiri 
penyitaan.

Kehadiran tergugat tidak menjadi syarat keabsahan pelaksanaan sita.

d. Juru sita dibantu dua orang saksi

a) Dijelaskan nama, pekerjaan, dan tempat tinggal saksi dalam berita acara sita

b) Saksi harus penduduk Indonesia,

c) Paling rendah berumur 21 (dua puluh) tahun.

d) Orang yang dapat dipercaya.

e) Pelaksanaan sita dilakukan di tempat barang terletak

f) Juru sita dan saksi datang di tempat barang yang hendak disita dan

g) Tidak sah penyitaan yang tidak dilakukan di tempat barang terletak.

h) Membuat berita acara sita

Hal-hal pokok yang harus dimuat dalam berita acara sita jaminan:

1) Tanggal dan nomor Surat penetapan.

2) Jam, tanggal, hari, bulan. dan tahun penyitaan.

3) Nama, pekerjaan, dan tempat tinggal saksi,

4) Rincian satu per satu jenis barang yang disita,

5) Penjelasan pembuatan berita acara dihadapan tersita (jika hadir),

6) Penjelasan penjagaan barang sitaan diserahkan kepada tersita dan

7) Ditandatangani.juru sita dan saksi.

i) Meletakkan barang sitaan di tempat semula

j) Menyatakan sita sah dan berharga

4. Sita jaminan atas barang tidak bergerak

Adapun ketentuan yang berlaku terhadap sita jaminan atas barang tidak bergerak, diantaranya seperti berikut: a. Penjagaan barang sita jaminan Secara tegas diatur dalam Pasal 508 Rv, dalam hal penjagaan sita jaminan barang tidak bergerak:

1) Tersita menjadi pen.jaganya, dan

2) Sifatnya demi hukum

b. Boleh dipakai tersita

Hal ini juga diatur dalam Pasal 508 Rv, dan dapat dijadikan pedoman kebolehan pemakaian barang sitaan, dengan syarat:

1) Pemakaian tidak boleh berakibat pada turunnya harga barang sitaan atau habisnya barang sitaan dalam pernakaian.

2) Bila harganya turun, tergugat diancam membayar ganti rugi dan bunga.

c. Penerapan sita penyesuaian tidak mutlak

Dalam penyitaan barang bergerak berlaku secara mutlak asas saisie a saisie ne vain yang digariskan Pasal 463 Rv, yaitu melarang sita rangkap atas barang bergerak dalam waktu yang bersamaan. Yang barang bergerak yang boleh dibebankan adalah sita penyesuaian (vergelijkende beslag). Akan tetapi, bertitik tolak dari ketentuan Pasal 515 Rv, asas itu tidak mutlak berlaku terhadap sita jaminan barang tidak bergerak. Pemegang sita pertama dapat dikesampingkan oleh pemohon sita yang lain (belakangan), dengan acuan penerapan sebagai berikut:

a) Pada prinsipnya pemohon dan pemegang sita jaminan pertama, mempunyai kedudukan yang lebih tinggi dari kreditor yang lain.

b) Dengan demikian, apabila berita acara sita jaminan pemohon 
pertama telah diumumkan, permintaan sita maupun eksekusi yang diajukan kreditor lain, wajib ditolak atau dihentikan.

c) Akan tetapi, pengadilan melalui subrogasi dapat mendahulukan kreditor yang memohon penyitaan belakangan, apabila:

1) Telah terjadi tipu muslihat yang dilakukan pemohon pertama atau ada persekongkolan antara pemohon pertama dengan tersita (tergugat), bahkan dalam kasus penyitaan seperti itu, pemohon sita dan tersita dapat dihukum membayar ganti rugi atas tipu muslihat atau persekongkolan itu.

2) Lalai mendaftarkan dan mengumumkan berita acara sita, sudah dijelaskan, sesuai ketentuan Pasal 214 RBg, sita jaminan atas barang tidak bergerak, baru mempunyai kekuatan mengikat kepada pihak ketiga, terhitung sejak tanggal pendaftaran dan pengumuman berita acara sesuai dengan Pasal 213 RBg.

Dengan dennikian, apabila sita jaminan yang dipegang pemohon pertama tidak didaftarkan dan diumumkan, hal tersebut dapat memberi hak dan peluang bagi pemohon yang belakangan untuk mendaftarkan dan mengumumkan sita yang dijalankan atas permintaannya. Oleh karena sitanya yang lebih dahulu didaftarkan dan diumumkan dapat menjadi dasar alasan untuk menyingkirkan sita jaminan yang pertama.

Asas vergeijkende beslag yang digariskan Pasal $436 \mathrm{Rv}$ terhadap sita jaminan atas barang tidak bergerak, tidak bersifat mutlak. Dalam kasus yang telah disebut di atas, asal dapat dibuktikan adanya tipu muslihat atau persekongkolan yang dilakukan pemohon pertama, prinsip sita penyesuaian bisa disingkirkan. Atau sampai pada saat diajukan permohonan sita oleh kreditor lain, sita yang pertama belum didaftarkan dan diumumkan. Namun kasus seperti ini, dianggap tidak rasional. Bukankah yang wajib mendaftarkan dan memerintahkan pengumuman adalah pengadilan negeri melalui juru sita ? Jika demikian halnya, dianggap tidak masuk akal apabila terjadi peristiwa pemohon terakhir mendapat peringkat teratas alasan sita pertama lalai atau tidak didaftarkan dan diumumkan.

d. Pengadilan dapat memerintahkan penggugat memberi jaminan Pedoman ketentuannya terdapat pada Pasal 722 Rv:

1) Ketua Pengadilan Negeri atau majelis dapat memerintahkan kepada penggugat sebagai pemohon sita untuk memberi uang jaminan atas penyitaan.

2) Uang jaminan itu meliputi biaya kerugian dan bunga yang timbul akibat penyitaan.

3) Uang jaminan diberikan bersamasama dengan perintah sita jaminan,

4) Selama uang jaminan belum diserahkan penggugat, sita jaminan tidak dapat dijalankan.

e. Berhak mengajukan bantahan atau perlawanan

Terhadap sita jaminan barang tidak bergerak dapat diajukan bantahan atau perlawanan :

1) Bantahan oleh tersita (tergugat):

a) dapat diminta dan diajukan 
tergugat dalam sidang insidentil yang khusus untuk itu, atau

b) pada proses pemeriksaan pokok perkara dalam persidangan. Bunyi bantahan meminta agar sita diangkat atas alasan tidak memenuhi syarat atau barang yang disita bukan milik tergugat

c) atau atas alasan dalil gugatan tidak mempunyai dasar hukum.

2) Perlawanan dari pihak ketiga (derden verzet)

Kalau bantahan dari pihak tergugat berpedoman kepada Pasal 724 Rv maka derden verzet atas sita jaminan (verzet door derden tegen beslag) menunjuk kepada ketentuan Pasal 206 RBg atau Pasal $378 \mathrm{Rv}$, atas alasan:

a) Barang yang disita milik tergugat, tetapi milik pelawan dan

b) Perlawanan diajukan dalam bentuk gugatan perlawanan degnan cara menarik penggugat (pemohon sita) dan tergugat (tersita) sebagai pihak terlawan.

\section{SIMPULAN}

Pelaksanaan Pasal 1131

KUHPerdata atas jaminan sertifikat hak tanggungan yang tidak diperjanjikan dengan mengajukan gugatan perdata melalui pengadilan. Untuk mendapat kepastian bahwa debitor akan memenuhi kewajibannya sebagaimana yang ditetapkan, penggugat dalam gugatannya harus meminta putusan provisional, yaitu meminta diletakkan sita jaminan. Apabila debitor dikalahkan akan tetapi tidak mau melaksanakan putusan secara sukarela, maka kreditor dapat meminta bantuan Ketua Pengadilan Negeri untuk melaksanakan putusan itu secara paksa. Pelaksanaan putusan pengadilan dengan melalui peringatan. Jika sudah lewat jangak waktu yang ditetapkan pengadilan pihak yang dikalahkan tidak memenuhi putusan maka harta benda debitor dijual melalui lelang.

\section{DAFTAR PUSTAKA}

Badrulzaman Mariam Darus, dkk, 2001, Kompilasi Hukum Perikatan, PT. Citra Aditya Bakti, Bandung

Engelbercht, Himpunan Peraturan PerundangUndangan Menurut Sistem Engelbrecht, Buku I, Tata Negara, Perdata, Dagang, Pidana, (Jakarta: Ichtiar Baru Van Hoeve, 2007), hlm. 671 dan 673

Harahap Yahya. 2005, Hukum Acara Perdata Tentang Gugatan, Persidangan, Penyitaan. Pembuktian dan Putusan Pengadilan. (Jakarta; Sinar Grafika.

Hermansyah, 2005, Hukum Perbankan Nasional Indonesia, Jakarta, Prenada Media

Kamelo Tan, 2004, Jaminan Fidusia Suatu Kebutuhan yang Didambakan, Bandung, Penerbit Alumni

Karjadi M,. 1991, Reglemen Indonesia yang Diperbaharui, S 1941 No. 44, RIB (HIR). Bogor; Politeia

Puspa Yan Pramadya, 1977, Kamus Hukum, Edisi Lengkap. Bahasa Belanda Indonesia Inggris, Semarang: Aneka Ilmu

Satrio J., 2001, Hukum Perikatan, Perikatan yang Lahir dari Perjanjian, Buku I, Bandung, PT. Citra Aditya Bakti

Subakti, 1977, Hukum Acara Perdata, Jakarta: Bina Cipta

Subekti R., 1980, Pokok-Pokok Hukum Perdata, Jakarta, Penerbit PT. Intermasa 1985, Hukum Perjanjian, Penerbit Intermasa, Jakarta

Sudikno Mertokusumo, 2002, Hukum Acara Perdata. Yogyakarta: Liberty

Sutantio Retnowulan dan Oeripkartawinata Iskandar, 1997, Hukum Acara Perdata dalam Teori dan Praktek, Bandung, 
Penerbit Mandar Maju

Suyatno Thomas, dkk., 1990, Dasar-dasar Perkreditan, Jakarta, Penerbit PT. Gramedia

Widjaya Gunawan dan Yani Ahmad, 2011, Jaminan Fidusia, Jakarta, PT. Raja Grafindo Persada

Undang-Undang No. 10 Tahun 1998 Tentang Perubahan atas Undang-Undang tahun 1992 tentang Perbankan

Kitab Undang-Undang Hukum Perdata Kitab Undang-Undang Hukum Acara Perdata

Keputusan Ketua Mahkamah Agung Republik Indonesia Nomor : KMA/032/SK/IV/2006 angka ke-2 huruf $\mathrm{C}$. 